\title{
PERANCANGAN INTERFACING KOMPUTER
}

\author{
(SCHEME OF INTERFACING COMPUTER)
}

\author{
Adhi Kusmantoro \\ Jurusan Teknik Elektro Fakultas Teknik Universitas Semarang
}

\begin{abstract}
Many existing software, the providing of facility of expansion and also price which is cheap relative, representing some fast cause him usage of IBM computer of PC in so many area. IBM of PC provide slot of expansion as mode to deal with external world. For the purpose needed technique of interfacing, that is installing card IBM slot of PC. In system requiring data input of parallel of PC can be used Parallel Port with Mode Standard to run process. Development of technique of interface application at minimum system of DST-51. Application of technique of interface this used many system alarm, universal control remote, data wireless of communication. Application of this interface can be used as Wireless Printer by enhancing Module of Infrared Transceiver like IR8510 for communications to use media of infrared and or Module of FM Transceiver for communications to use media waving FM and a microcontroller to deal with printer to print. This Inteface eam also used for the application of usage a PC Parallel Port by some fruit of printer at the same time so that the printer-printer will print data delivered by $P C$ concurrently in place which is far (for the FM OF Wireless Communication).
\end{abstract}

Keywords: Interfacing DST-51, Infrared Transceiver, RS 485

\section{Pendahuluan}

Salah satu komponen

pembentuk sebuah komputer adalah komponen LSI (Large Scale Integration ) yang menunjukkan teknologi baru yang memadukan ribuan transistor pada satu rangkaian terpadu atau yang biasanya disebut IC (Integrated Circuit). Dan komponen lainnya yang terpenting adalah mikroprosesor yaitu suatu komponen LSI yang melaksanakan hampir semua fungsi sebuah prosesor pada sebuah serpih (Chip). Bersama dengan komponen LSI lainnya, mikroprosesor dipakai untuk membuat sebuah komputer. Mikroprosesor melaksanakan sebagian besar fungsi atau kerja unit pemroses. Mikroprosesor mempunyai tiga komponen lainnya melaksanakan fungsi memori, masukan/keluaran dan fungsi lain yang dipertukan. Unit pemroses pusat ( Centarl Processing Unit,
"CPU") atau prosesor terdiri dari dua unit yaitu :

* Unit pengendali (Control Unit,"CU")

* Unit Aritmatika dan logika ( Arithmatic and Logic Unit, "ALU")

Unit aritmatika dan logika melaksanakan operasi aritmatika dan logika untuk data yang melaluinya. Fungsi utama unit kontrol adalah mengambil, mendekode (menafsirkan kode/sandi) dan melaksanakan urutan instruksi sebuah program yang tersimpan dalam memori. Unit kontrol mengatur seluruh operasi sistem. Khusus unit ini membagkitkan sinyal kontrol yang diperlukan untuk mensinkronkan operasi, selain juga aliran data dan instruksi program di dalam dan diluar ALU. Mikroprosesor mempunyai tiga bus :

* Bus data
* Bus alamat

* Bus kontrol Kontrol

unit mengedalikan aliran informasi pada bus data dan bus alamat, kemudian menafsirkan mengatur sinyal yang terdapat pada bus kontrol. Sebuah bus adalah sarana untuk mengirim sinyal (informasi). Ketiga bus standar yang digunakan untuk menghubungkan sistem mikroporsesor adalah bus data, bus alamat dan bus kontrol Unit kontrol pada umumnya dihubungkan dengan ALU yang dikendalikannya. Perlu diingat bahwa kombinasi ini (CU dan $A L U)$ disebut unit pemroses pusat (CPU). Jadi, pada dasamya sebuah mikroprosesor adalah CPU pada seluruh serpih. Untuk menyimpan informasi sistem komputer menggunakan modul memori. Dan sebagai unit masukan (Input) adalah keyboard 